$14: 478$

<原 著 $>$

無症候性原発性胆汁性肝硬変の肝外門脈シャント

$\begin{array}{cccccccc}\text { 瀬在 } & \text { 秀一 } & \text { 桜林 } & \text { 真 } & \text { 山本 } & \text { 佳洋 } & \text { 吉浦 } & \text { 健太 } \\ \text { 吉野 } & \text { 克正 } & \text { 清水 } & \text { 敏朗 } & \text { 森田 } & \text { 敏和 } & \text { 平野 } & \text { 正憲 } \\ \text { 岩瀬 } & \text { 透 } & \text { 岡 } & \text { 博* } & \text { 鈴木 } & \text { 恒道** } & & \end{array}$

要 旨：健診などで偶然発見された器症候性原発性胆汁性肝硬变 5 例に対し経皮経肝門脈造影 (PTP)抽よび超音波パルスドッブラー法により門脈血行動態を解析し, 病理学的所見との対比 を行った．PTPで 5 例中 4 例 (80\%) に肝外側副血行路を認めた。内訳は胃腎シャント 3，脾 腎シャント 1 , 後腹膜シャント 1 例であった. 門脈血流量は $654 \pm 158 \mathrm{~m} l / \mathrm{min}$ と正常対照群と比 べ有意差はなく, 門脈厈（PVP）は1例を除いて全例正常に維持されていた，病理学的検討を 行った 4 例中 3 例に presinusoidal block と考えられる門脈枝の狭小化を認め, 門脈圧元進症 (PVP 23 $\mathrm{cmH}_{2} \mathrm{O}$ ) を呈した 1 例では presinusoidal から sinusoidal k至る変化があった。

以上の結果上り原発性胆汁性肝硬变では極く早期より肝外門脈シャントを呈することがある と結論された。

索引用語： a-PBC PTP 肝外門脈シャント

はじめに

原発性胆汁性肝硬变 (PBC) の診断は IgM や抗ミト コンドリア抗体 (AMA) 測定などにより，比較的容易 になされるよらになり，無症候期（a-PBC）に発見さ れるケースが多くなっている。一方，食道静脈痖や肝 性脳症などの門脈止六進症症状を呈し,そのため PBC が早期に診断されたとする報告る散見される に，超音波検查の進歩により，門脈系などの㳭部血管 血流量る非侵襲的に測定し得るよ5になった。われわ れは肝生検による確定診断のため入院したa-PBC 症 例の超音波検查で側副血行路を認めた症例があったた め, 以後 a-PBC 症例に経皮経肝門脈造影(PTP)を行 い門脈血行動態について検討した。

\section{対象と方法}

対象は1988年 4 月以降，1989年10月まで当院外来で a.PBC を疑われ，その精査のため入院した以下の 5 症 例である。

症例 $1: 55$ 歳女, 健診で肝機能異常を指摘され当院 受診. GOT 85KU, GPT 76KU, LDH 263IU, Al-P 42.1KAU, $\gamma$-GTP $212 \mathrm{U}$, AMA (+) $1,280 \times$, IgM $2,050 \mathrm{mg} / \mathrm{d} l$.

\footnotetext{
* 東京鳘察病院消化器センター内科

**同病理
}

〈受付日1990年10月 4 日>
症例 $2: 51$ 歳女, 近医より胆裹ボリープ精查依頼で 当院受診. GOT 33, GPT 27, LDH 261, Al-P 27.2, $\gamma$-GTP 117, LAP $454 \mathrm{mU} / \mathrm{m} l, \operatorname{AMA}(+) 80 \times, \operatorname{IgM}$ 1,003 .

症例 3:51藏男, 健診で肝機能異常を指摘され当院 受診. GOT 33, GPT 28, LDH 326, Al-P 10.6, $\gamma$-GTP 181, LAP 310, AMA (+) 160×. IgM 492.

症例 $4: 45$ 歳女, 健診で $\gamma$-GTP の高值を指摘され 当院受臸したが, 他の肝機能検查る増悪したため入院. GOT 45, GPT 62, LDH 261, Al-P 12.4, $\gamma$-GTP 126, LAP 336, IgM 606, AMA $(+) 640 \times$.

症例 $5: 54$ 藏女, 健診で肝障害指摘され精査目的で 入院. GOT 49, GPT 38, LDH 362, Al-P 18.5, $\gamma$-GTP 114, LAP 462, IgM 440, AMA ( + ) $120 \times$.

全例黄疾，搔痒感などはなく，無症状であり食道静 脈瘤, 脾腫など認めなかった。 a-PBC の診断はRoll ら の基準战に従った。 PTPにより，肝門部で 2 回門脈圧 (PVP) を測定しその平均をPVP值とし，次に全例に $5 \mathrm{~m} l / \mathrm{sec}$, 総量 $30 \mathrm{~m} l$ の同一条件で脾静脈, 上腸間膜静 脈上り造影を行い，肝外シャント，肝内門脈像を検討 した．症例 5 のみ造影効果を鮮明にするためにさらに $4 \mathrm{~m} l / \mathrm{sec}, 20 \mathrm{~m} l$ で側副血行路である左胃静脈より造影 した。肝生検は全例針生検 (Trucut ${ }^{(B)}$ ) で行い, 病期 分類は Scheuer の基準 ${ }^{6}$ に従った。聞脈血流量（PVf） 
は超音波バルスドッブラー法(ALOKA SSD-650,ドッ プラーュニット)により早朝空腹時に行い，正常対照 群として当院人間ドック患者 $(\mathrm{n}=110$, 平均51歳, 男 72，女38）と比較した.

\section{結 果}

\section{1) 門脈血行動態}

症例 1：Fig. 1のPTP 像では胃堅シャントを認め

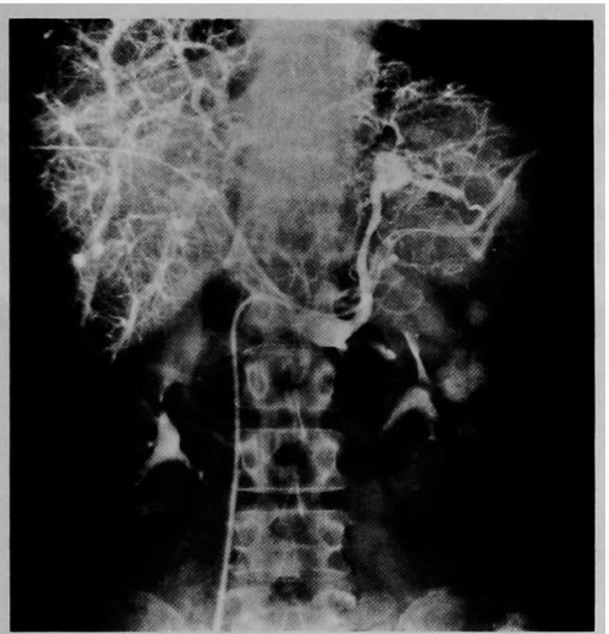

Fig. 1 By injecting a contrast medium into the splenic vein, the portovenous connection from the short gastric vein to left renal vein is revealed.

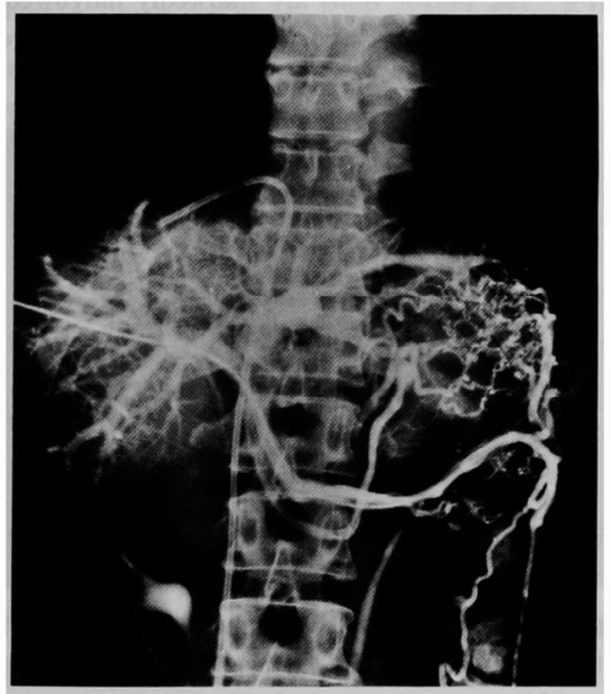

Fig. 2 By injecting a contrast medium into the splenic vein, there are revealed the portovenous connection from the short gastric vein to left renal vein and the retroperitoneal collateral vein.
PVP $23 \mathrm{cmH}_{2} \mathrm{O}$, PVf $615 \mathrm{ml} / \mathrm{min}$. 症例 2 ：胃腎シャント, 後腹膜シャントを認め(Fig. 2), PVP 6, PVf 470 .

症例 3 ：脾卧シャントを認め(Fig. 3), PVP 9, PVf 890.

症例 4 ：シャントを認めず (Fig. 4). PVP 5, PVf 714.

症例 5：胃堅シャント(Fig. 5), PVP 5, PVf 580. 以上 5 例中 4 例に側副血行路を認めたが，肝内門脈

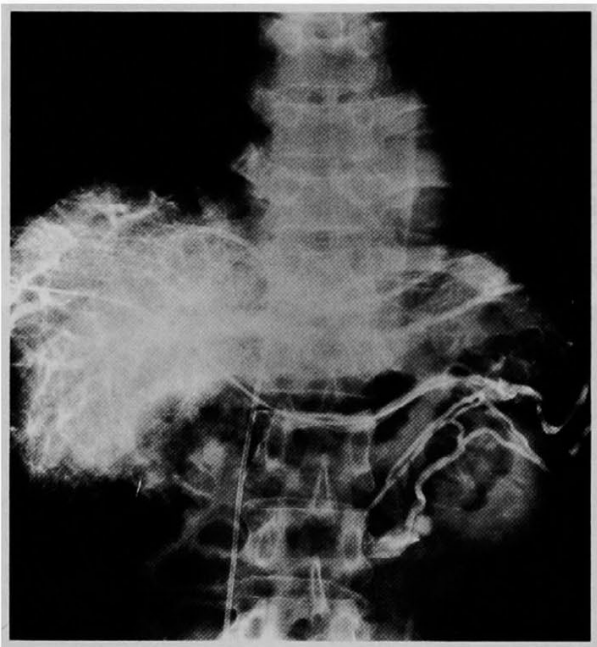

Fig. 3 The portovenous connection from the splenic vein to the left renal vein is revealed by injecting contrast medium into the splenic vein.

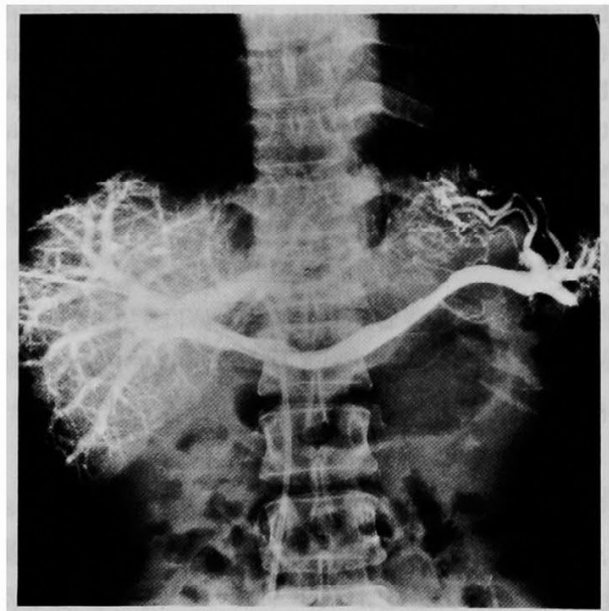

Fig. 4 No extrahepatic collateral vein is visualized by injecting a contrast medium. 


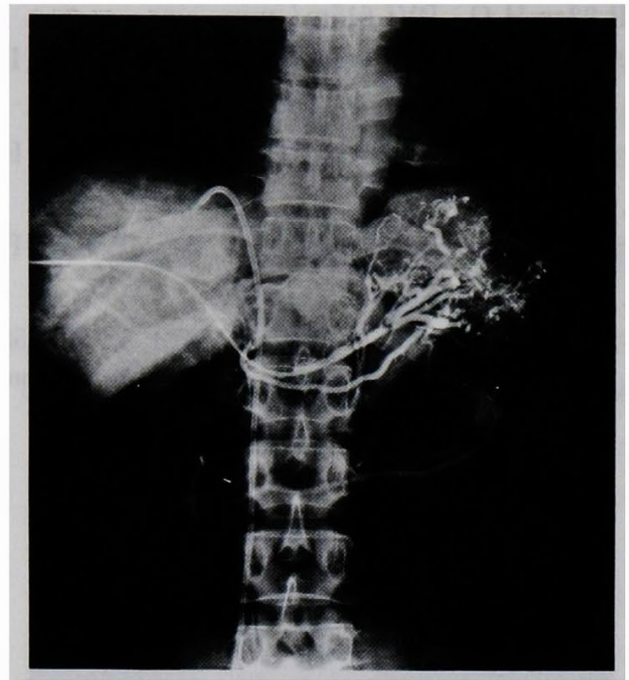

Fig. 5 The left gastric vein is filled with a contrast medium, draining toward the left renal vein.

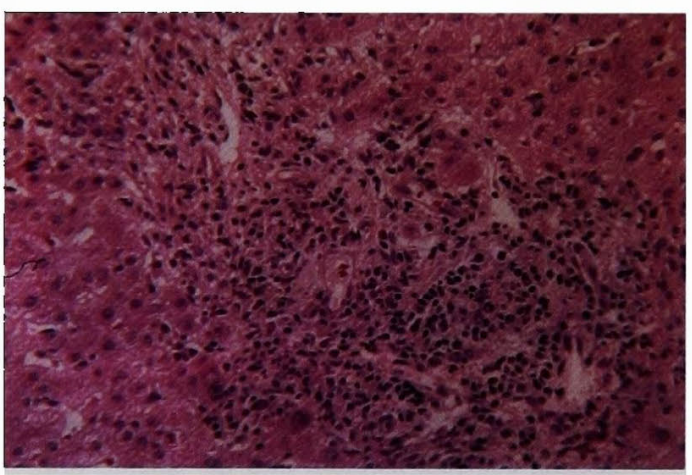

Fig. 6 Marked fibrosis destructing portal tract beyond the limiting plate and lymphocytic infiltration are recognized. Interlobule bile duct can be seen in the only one of nine available portal tract, and the remarkable narrowing of the portal veins is recognized. Hepatocytes are swollen and degenerative with irregular arrangement to be diagnosed as Scheuer 2.

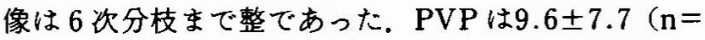
5)で 1 例を除き正常であり，PVf は654士158と正常対 照群685士201と比較して差はなかった。

\section{2) 病理所見}

症例 1 ：(Fig. 6) グ䩬に限界板を越える fibrosis 著 しく，リンパ球を主体とする細胞浸潤著明で肉芽腫, piecemeal necrosis を形成. 9 個のグ䩗のらち 1 力所 のみに小葉間胆管が見られるだけで門脈は狭小化著明 であった，肝細胞は腫大変性強く，配列の乱れあり，

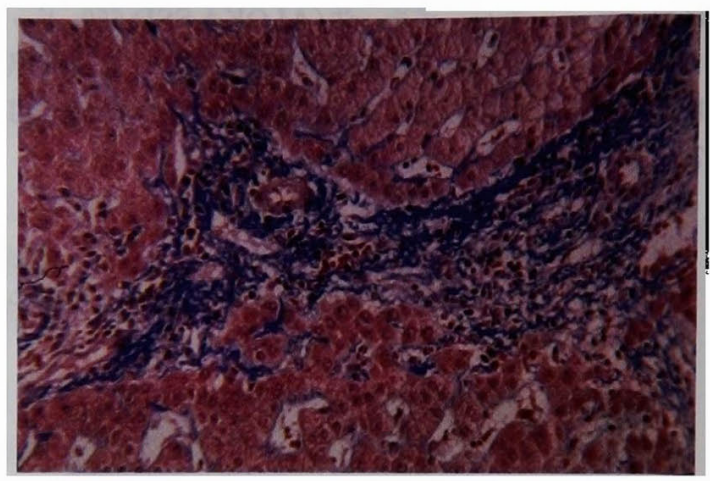

Fig. 7 Lymphocytic infiltration is mildly recognized in the seven available portal tract. There are no narrowing of the portal veins and hepatocytes are in the regular arrangement.

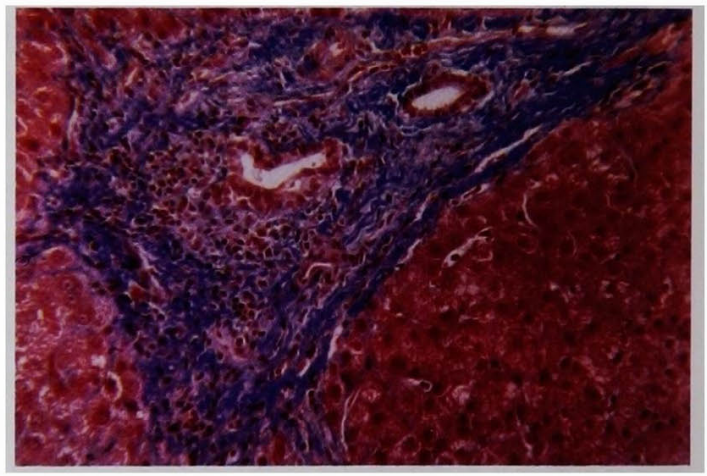

Fig. 8 The portal veins are markedly narrowed, and the chronic nonsupprative destructive cholangitis is present to qualify Scheuer 1.

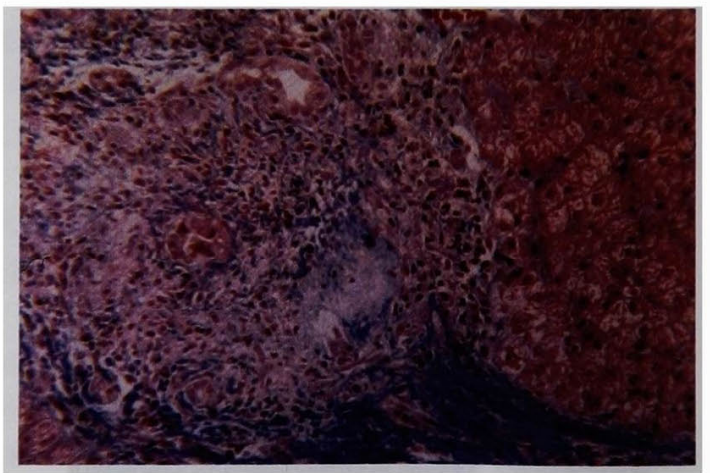

Fig. 9 Lymphocytic infiltration is recognized in these 18 portal tract and hepatocytes are in the regular arrangement; in half of them, there are remarkable narrowing of the portal veins, the destruction of interlobule bile duct, and granuloma; partial crystalization and scarring are revealed to qualify Scheuer $2 \sim 3$. 
Scheuer 2 期と診断された (HE 染色).

症例 $2 ：$ (Fig. 7) 7 個のグ䩗にリンパ球を主体とす る軽度細胞浸潤あり．小葉間胆管のつぶれはあるるの $の$, CNSDC (chronic nonsuppurative destructive cholangitis）の所見はなく，明瞭な門脈の决小化を認 めず，䀒細胞索は保たれていた．SCheuer 分類は不明 (Masson 染色).

症例 3：(Fig. 8)12個のグ䩗のらち3個にリンハ球 を主体とする細胞漫潤がみられ，CNSDCを 2 力所に 認め，門脈の狭小化を認める。肝細胞索は保たれてお り. Scheuer の 1 期 (Masson 染色).

症例 4：(Fig. 9)18個のグ䩗中にリンパ球を主体と する細胞漫潤あり。グ鞴の半数に小葉間胆管の消失, 肉芽庫を認め, 一部硝子化症痕あり，門脈の狭小化が 著明. 盰細胞索は比較的保たれており，Scheuerの 2 ～ 3 期 (Masson 染色).

症例 5 は採取された組織上，ク䩗が 1 個しが含まれ ずに判定不能であった。

\section{考案}

a-PBC からの症候性 PBCへの移行に関する報告は 多数 ${ }^{7,3)}$ あ，その移行率は様々であり，両病態の連続 性についても議論のあるところである，両者の共通の 所見として門脈圧穴進症があげられ，a-PBCにおいて す食道静脈瘤破裂や肝性脳症を初発とした症例報告が 散見されるい。

聞脈圧は従来より backward theory, forward theoryに代表されるように門脈血流量, 肝内血管坻抗によ り規定される。 その意味では今回の症例は門脈血流量 は全例正常に維持されており，4例の門脈圧は正常で あったが，病理学上評価し得た 4 例中 2 例に presinusoidal block 示唆する病理所見が認められ， 一方 1 例を除いて sinusoidal level での変化は乏し かった，そのため，われわれの症例の中に idiopathic portal hypertension (IPH) 例の存在の可能性も考之 られた。 IPH の場合 PTP 像の肝内門脈枝は 3 次分枝 より問題とされており，その所見として門脈末梢枝の らねり，からまり状変化，肝縁との間の avascular area が指摘されていろが9)，今回の症例では造影され 得た 6 次分枝の level までは壁の不整は認められず, 病理学的門脈変化は 7 次分枝以下の变化々考克られ た。さらにIPH に特徵的とされる㵶維化,異所性門脈, 門脈枝の潰れなどの所見はみられなかった，従来より PBCでは病変の主座が胆管系に向けられており，代表 的な Scheuer 分類です門脈系の記戴はなく，逆に IPH
では胆管系の記載は少ない.PBCの門脈系の検討の一 つに，実醅モデルとして变異化菌体成分の門脈注入が 試みられており ${ }^{10)}$, 病理学的に門脈の㹟小化・硬化性变 化 ${ }^{3)}$ ，門脈周囲炎 ${ }^{11)}$ ，肉芽腫形成など門脈枝への压迫に よる presinusoidal block ${ }^{12)}$, 肝内に局在する regenerative nodular hyperplasia Kよる影響常が考 察されている。さらに門脈血行動態と関連付けて aPBC の病理学的変化を論じた報告も多くない，この点 につき，Nakanuma ら゙は食道静脈瘤の有無による病 理所見の差について検討を加え，静脈癉陽性例に門脈 狭小化，硬化像が認められることを報告している。こ のような症例は胃腎シャントを呈し，将来胃静脈瘤に 進展することが予想される，今回の症例 1 に相当する と考えられ，門脈圧穴進症を初発とする a-PBCの報告 例に一致すると思われる。.さらに残りの 4 症例は門脈 王が正常域に維持されているものの，3例が外シャン 卜形成， 2 例に門脈の狭小化を認め一時的な門脈压六 進の介在, 先天性外シャントの存在が示唆された。先 天性の portocaval shunt ${ }^{13,14)}$ とては，それを示唆す る巨大なシャント所見はなく否定的である. Navasa $ら^{11}$ は肝静脈揳入王一肝静脈王較差により32例中 5 例 に压較差正常 ( $6 \mathrm{mmHg}$ 以下)の静脈瘤陽性例を報告し ており，Ludwig 分類で全例 stage 2であったとしてお ク, 今回のわれわれの症例 3 と同様のものと思われる. さらに应例 4 では presinusoidal の変化が認められた にす関わらず外シャントがなく，症例 2 では presinusoidal な変化が認められなかったにも拘わら ず外シャントを認めたよらに種々のパターンを旺し た.これはPBCの極く初期像をみているためであり， 症例 1 の様な状況にいたるまでには一定の期間が必要 なためと考えられた。

おわりに

本研究で示したよらにPBCの極く初期段階で肝外 門脈シャントが高率に発生する，従来より，PBCでは 胆管系に主眼が注がれる㑯向にあったが，今後門脈采 も注目すべきであろう。かつ，a-PBC 症例に道遇した 場合には，門え症か隠されていることを念頭に診療に 当たる必要があろう。

\section{文城}

1) Beswick DR, Klatskin G, Boyer JL: Asymptomatic primary biliary cirrhosis. A progress report on long-term follow-up and natural history. Gastroenterol 89 : 267-271, 1985 
2) Zeegen R, Stansfeld AG, Dawson AM, et al : Bleeding oesophageal varices as the presenting feature in primary biliary cirrhosis. Lancet $2: 9$, 1969

3) Nakanuma $Y$, Ohta G, Kobayashi $K$, et al : Histological and histometric examiation of the intrahepatic portal vein branches in primary biliary cirrhosis without regenerative nodules. Am J Gastroenterol 77 : 405-413, 1982

4) Nakanuma $Y$, Ohta G: Nodular hyperplasia of the liver in primary biliary cirrhosis of early histological stages. Am J Gastroenterol $82: 8$ $-10,1987$

5) Roll J, Boyer TL, Barry D, et al: The prognostic importance of clinical and histologic features in asymptomatic and symptomatic primary biliary cirrhosis. N Engl J Med 308 : 1 $-7,1983$

6) Scheuer PJ : Primary biliary cirrhosis. Proc $\mathbf{R}$ Soc Med $60: 1257-1260,1967$

7) Kapelman B, Schaffner F: The natural history of primary biliary cirrhosis. Semin Liver Dis 1 : 273-281, 1981

8) Balasubramanian K, Grambsch PM, Wiesner $\mathrm{RH}$, et al: Asymptomatic primary biliary cirrhosis (PBC): Patients have a diminished survival. Hepatology $7: 1025,1987$

9) Futagawa $S$, Fukazawa $M$, Horisawa $M$, et al: Photographic liver changes in idiopathic noncirrhotic portal hypertension. Am J Radiol 134 : $917-923,1980$

10) Stemerowics R, Hopf U, Galanos $C_{\text {, et al : Are }}$ antimitochondrial antibodies in primary biliary cirrhosis induced by R(rough)-mutant of enterobacteriaceae? Lancet 19:1166-1169, 1988

11) Navasa $M$, Pares $A$, Brugvera $M$, et al : Portal hypertension in primary biliary cirrhosis relationship with histological features. J Hepatol 5 : 292-298, 1987

12) Sherlock $S:$ Primary biliary cirrhosis. In : Popper H, Schaffner F, eds. Progress in liver disease. Vol V, New York, Grune \& Stratton

13) Reichardt W, Butzow GH, Erbe W: Anomalous venous connections involving the portal system. Cardiovasc Radiol 2 : 41-46, 1979

14) Kerlan RK, Sollenberger RD, Palubinskas AJ, et al: Portal-systemic encephalopathy due to congenital porto caval shunt. Am J Radiol 139 : $1013-1015,1982$

\title{
Extrahepatic portovenous shunts in asymptomatic primary biliary cirrhosis
}

\author{
Shuichi Sezal, Shin Sakurabayashi, Yoshihiro Yamamoto, Kenta Yoshiura, \\ Katsumasa Yosmino, Toshiaki SHmmzU, Toshikazu MoRITA, \\ Masanori HIRaNo, Tohru IwaSE, Hiroshi OKa* \\ and Tsunemichi SuzUKI**
}

Extrahepatic portovenous shunts were demonstrated in 4 of the 5 patients with asymptomatic primary biliary cirrhosis (a-PBC) ( 3 gastro-renal shunts, and one each of spleno-renal and retroperitoneal shunts). We found no statistical differences in the results through comparative studies between a-PBC patients and control subjects in regard to portal venous blood flow (PVf). Portal venous pressure was within normal limits in $\mathbf{4}$ of the 5 studied patients. A presinusoidal block was histopathologically recognized in 2 of the three without portal hypertension, while a sinusoidal change was extensively noted in the remainder with portal hypertension. In conclusion, the extrahepatic portovenous shunt is formed in the very early stage of PBC along with other histopathological changes.

\footnotetext{
* Division of Gastroenterology, Tokyo Metropolitan Police Hospital (Tokyo)

** Division of Pathology, Tokyo Metropolitan Police Hospital (Tokyo)
} 